\title{
Is there a relation between hepatic fibrosis due to chronic hepatitis $B$ and $C$, and fibrosis of the lung?
}

\section{Kronik hepatit B ve C'ye bağll hepatik fibrozisin akciğerde fibrozis oluşumu ile ilişkisi var mı?}

\author{
Muhammet Arslan', Sinan Sozutok ${ }^{2}$, Özgür Külahci ${ }^{3}$, Erhan Uğurlu ${ }^{4}$ Mehmet Suat Yalçın ${ }^{5}$,
} Bozkurt Gullek ${ }^{6}$

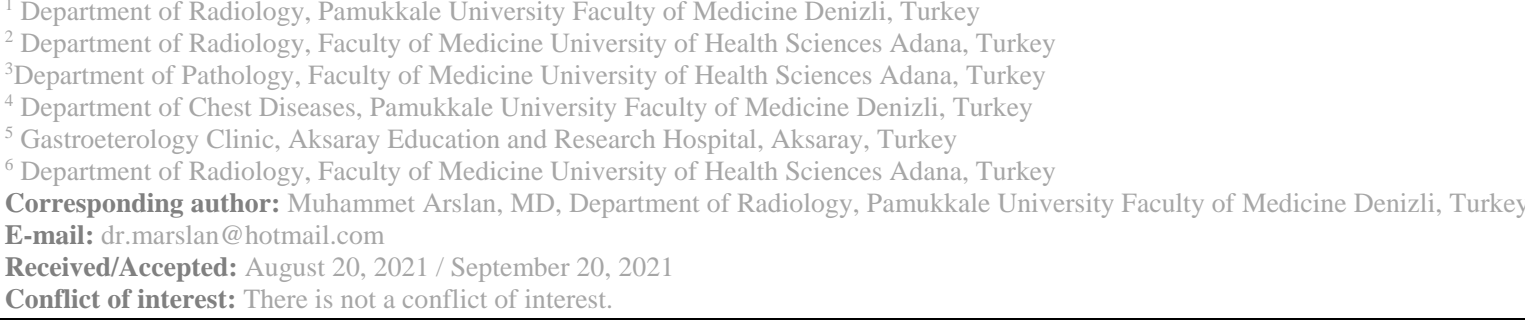

\section{SUMMARY}

Objective: The aim of this study was to find out if the process of hepatic fibrosis due to hepatitis B and C accentuates the development of fibrosis of the lungs.

Method: Cases with histories of parenchymal hepatic biopsies were scanned retrospectively, which had been biopsied due to hepatitis B and C diagnoses. Among these patients, those who had undergone a computed tomographic (CT) examination of the chest during the year following the biopsy procedure were investigated for signs of lung fibrosis. The hepatic biopsy results were categorized into two groups on the basis of the modified hepatic activity index, and these were evaluated in comparison with the lung fibrosis findings diagnosed at CT.

Results: Findings of lung fibrosis were found in $43.8 \%$ of the patients with hepatitis B and C. When the group with the pathological diagnosis of hepatic fibrosis (Stages 1-5) was compared with the no-hepatic-fibrosis group, it was found that no statistically significant difference existed between these two groups, in terms of positive or negative lung fibrosis findings at CT of the chest.

Conclusions: There is no correlation between the development of hepatic fibrosis and lung fibrosis.

Keywords: Computed tomography, fibrosis, hepatitis B, hepatitis C, lung

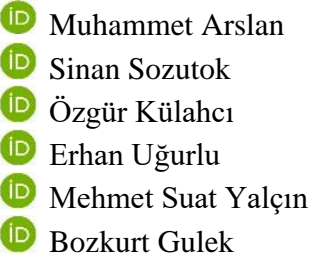

ORCID IDs of the authors: M.A. 0000-0001-5565-0770 S.S. $0000-0003-3626-2312$ Ö.K. 0000-0002-6636-1840 E.U. 0000-0001-5402-6925 M.S.Y. 0000-0003-1054-1882 B.G. 0000-0003-1510-6257

\section{ÖZET}

Amaç: Kronik hepatit B ve C'ye bağlı oluşan hepatik fibrozisin akciğerde de fibrozis oluşumunu artırıp artırmadığını araștırmaktır.

Yöntem: Hepatit B ve hepatit C nedeniyle yapılmış karaciğer parankim biyopsileri retrospektif olarak tarandı. Biyopsi tarihinden itibaren bir yıl içinde toraks bilgisayarlı tomografi çekilen hastalarda akciğerde fibrozis bulguları araştırıldı. Karaciğer parankim biyopsi sonuçları modifiye hepatik aktivite indekse göre 2 gruba ayrılarak toraks bilgisayarlı tomografide ki fibrozis bulguları ile karşılaştırıldı. 
Bulgular: Hepatit B ve C'li hastaların \%43.8'inde akciğerde fibrozis bulgularına rastlandı. Karaciğer patoloji sonucunda fibrozis olan grup (evre 1-5) ile fibrozis olmayan grup (evre 0) karşılaştırıldığında toraks BT'de fibrozis bulgusunun pozitif veya negatif olması açısından istatistiksel olarak anlamlı fark bulunamadı.

Sonuç: Hepatit B ve C'li hastalarda karaciğerde fibrozis oluşmasının akciğerde ki fibrozis oluşumu ile ilişkisi yoktur. Anahtar sözcükler: Akciğer, bilgisayarlı tomografi, fibrozis, hepatit B, hepatit C.

\section{INTRODUCTION}

Fibrosis may affect any organ, but the most frequently encountered chronic fibrosis diseases are hepatic fibrosis (HF) and pulmonary fibrosis (PF). ${ }^{1}$ The process of fibrosis is simply the accumulation of extracellular matrix elements in the injured tissue, following the migration and proliferation of fibroblasts. The growth factors (TDGF, PDGF, b-FGF, and TGF-B) and cytokines (IL-1 and TNF) secreted by the macrophages, leukocytes, and fibroblasts, stimulate the formation of collagen by means of induction of fibroblast migration and proliferation. ${ }^{2}$ These growth factors and cytokines which are effective in the development of HF also play a role in the development of $\mathrm{PF}^{2}$ Although common pathways exist between the development of both HF and PF, there have been only a few studies conducted on the issue. ${ }^{1}$ The reason why we performed this study was that we had the impression that the development of HF due to hepatitis B and C had an augmentative effect on the development of PF, by means of utilizing these common pathways.

\section{MATERIAL AND METHODS}

This study was conducted in accordance with the Declaration of Helsinki and the Good Clinical Practice Guide. Ethical approval was obtained from the Non-Interventional Clinical Ethical Committee of the University of Cukurova, School of Medicine (meeting number: 65; decision number 7). All liver parenchymal biopsies done at the Interventional Radiology Department between December 2014 and April 2017 were scanned retrospectively. It was found that in only 44 of the 684 patients biopsied, a computed tomographic CT examination of the chest had been performed due to various indications. In only 33 of these patients was there a time period of less than one year between the liver biopsies and chest CT examinations. One patient was excluded from the study because of the presence of multiple hepatic tumors besides hepatitis B. Inclusion and exclusion criteria are given in Table 1. The parenchymal liver biopsy results of the remaining 32 patients were categorized into two groups, as Grade 0 and Grade $1-6$, on the basis of the modified hepatic activity index (Table 2). The CT examinations of the thorax were evaluated by a radiologist, on the basis of the fibrosis findings. The grades of the liver fibrosis were compared with the results of the patients who showed fibrosis findings on chest CT.

Table 1: Patient eligibility

\section{$\underline{\text { Inclusion criteria }}$}

The approval of the informed consent forms by the patients

Patients in the 18-85 year age range

Patients who have been serologically diagnosed with hepatitis $\mathrm{B}$ and $\mathrm{C}$

Patients who have undergone a liver parenchymal biopsy procedure under imaging guidance

Patients who have been staged for fibrosis, in accordance with the biopsy findings

Patients in whom there have been a time period of less than one year between the liver biopsy procedure and the chest CT exam.

\section{Exclusion criteria}

Patients who do not comply with the above-mentioned inclusion criteriae

Patients with a chronic liver disease else than hepatitis B and C

Patients with hepatic encephalopathy

Patients whose data such as demographics, pathology results, and thorax CT examinations, could not be reached adequately 
Table 2: Modified histologic activity index

\begin{tabular}{|l|c|}
\hline Pathological Changes & Grade \\
\hline No fibrosis & 0 \\
\hline Fibrous enlargement and/or short fibrous septae in a few portal areas & 1 \\
\hline $\begin{array}{l}\text { Fibrous enlargement and/or short fibrous septae in most of the portal } \\
\text { areas }\end{array}$ & 2 \\
\hline $\begin{array}{l}\text { Fibrous enlargement and scarce portal-portal bridgings in most of the } \\
\text { portal areas }\end{array}$ & 3 \\
\hline $\begin{array}{l}\text { Fibrous enlargement and conspicuous bridgings (portal-portal or } \\
\text { portal-central) in most of the portal areas }\end{array}$ & 4 \\
\hline $\begin{array}{l}\text { Conspicuous bridgings (portal-portal or portal-central) and scarce } \\
\text { nodules (incomplete cirrhosis) }\end{array}$ & 5 \\
\hline Cirrhosis (probable or certain) & 6 \\
\hline
\end{tabular}

All liver parenchymal biopsy procedures were performed under the imaging guidance of a Mindray DC-7 ultrasonography (US) device (Medical International Limited, Shenzen, China), utilizing a $3.5 \mathrm{MHz}$ abdominal transducer. The chest CT examinations were carried by a 16channel multidetector CT machine (Optima 520, GE Healthcare, Milwaukee, Wisconsin, USA).

\section{Statistical Analysis}

All data were analyzed by the utilization of the Statistical Program for Social Sciences (SPSS) 22.0 pocket program. Continuous variables were designated with the mean and standard deviation (SD) parameters, whereas categorical variables were expressed by means of numbers and percentages. The differences among the categorical variables were studied by the Chi Square analytical method. On the other hand, the Logistic Regression Analysis method was used for the evaluation of the risk factors. $\mathrm{P}<0.05$ was appointed as the statistical significance level in all analyses.

\section{RESULTS}

18 of our patients were males, while 14 were females. The mean age was 51.3 years (range: $24-$ 82 years). 19 patients had been diagnosed with hepatitis B, whereas 13 were diagnosed with hepatitis C. No pathologies were detected at chest
CT examinations of 11 (34.4\%) patients, while in $14(43.8 \%)$ patients, findings of pulmonary fibrosis were found. Findings indicating fibrosis at chest CT were as follows: parenchymal bands in 9 patients, subpleural linear densities in 2 patients, interlobular septal thickenings in 2 patients (both parenchymal bands and interlobular septal thickenings in one patient), traction bronchiectasis and interlobular septal thickening in 1 patient. Figure 1 shows the CT image of the "parenchymal band", which is the most frequent finding. In none of our patients was there a honeycomb pattern, which is one of the end-stage findings of lung fibrosis. Findings of chronic obstructive pulmonary disease (COPD) were found in $8(25 \%)$ patients, while 2 patients had lung nodules, and 1 patient was diagnosed with lung consolidation due to contusion.

According to the biopsy results, only 2 patients demonstrated stage 5 cirrhosis findings. 3 patients with stage 0 categorization showed no findings of fibrosis. Liver biopsy results in accordance with the hepatitis B and C diagnoses are demonstrated at Table 3. On the other hand, the microscopic images of the fibrotic process in a patient who had been diagnosed with hepatitis B and who had a modified histologic active index of 3, are shown in Figure 2. 


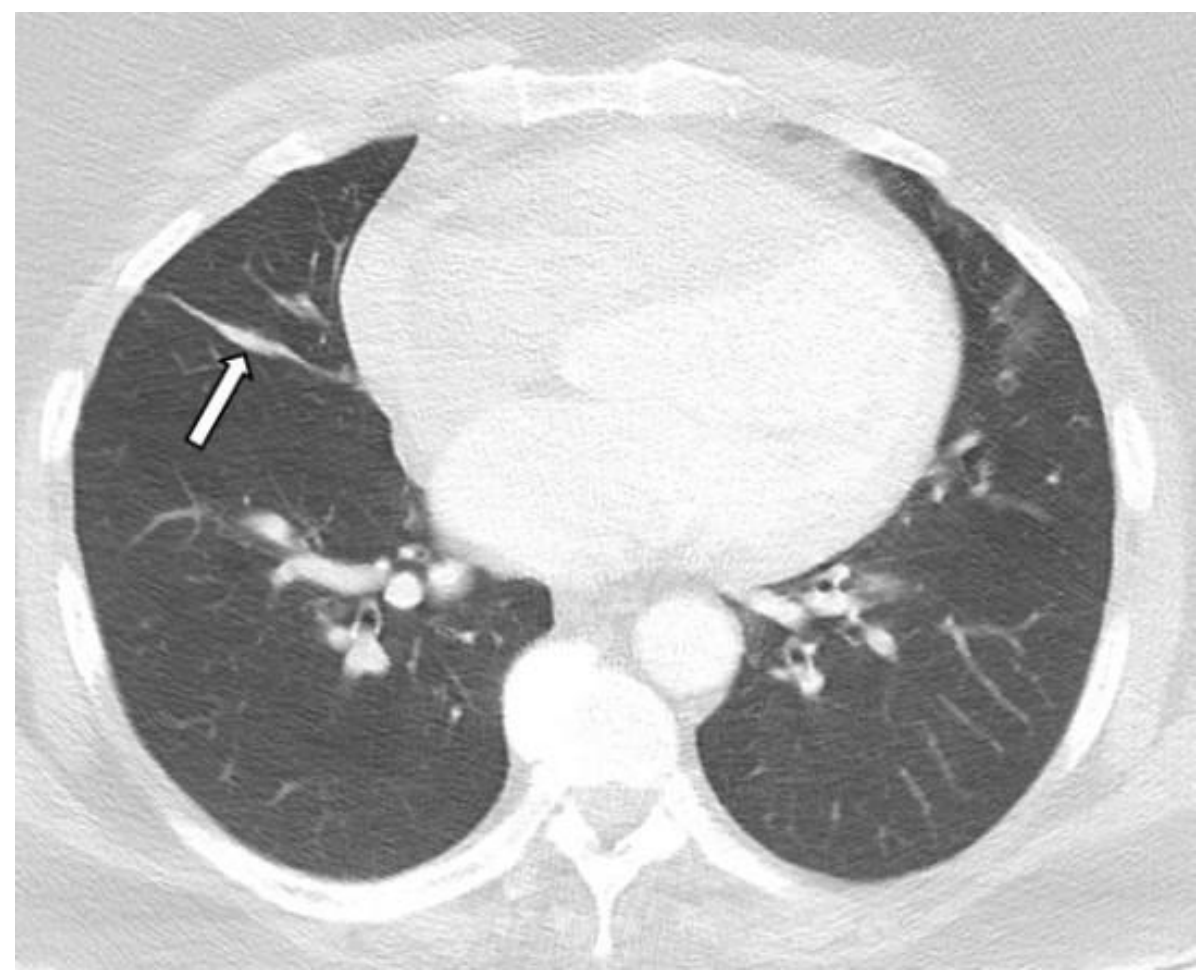

Figure 1: Axial CT scan shows parenchymal band (arrow) in the right upper lobe.

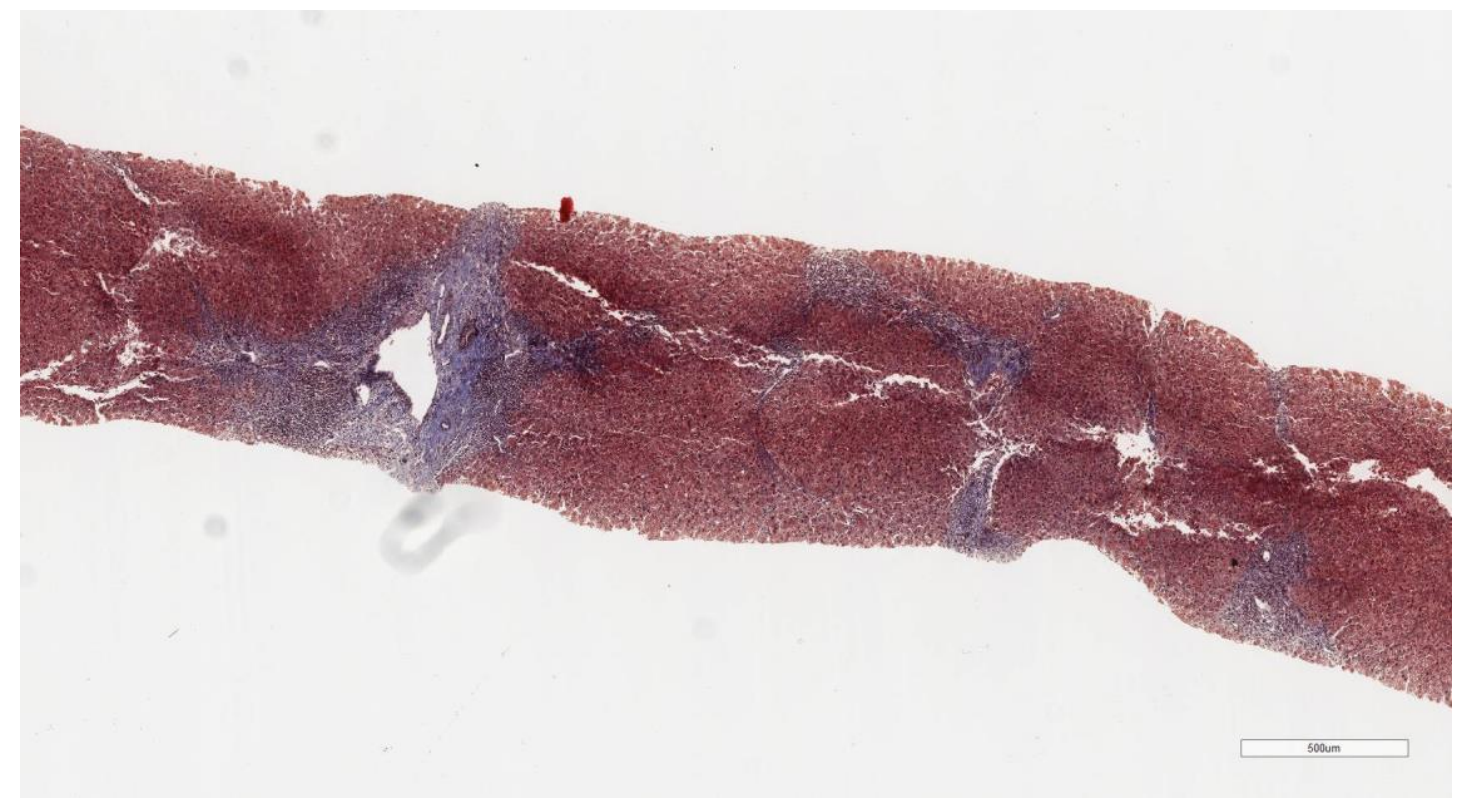

Figure 2: Porto-portal bridging fibrosis in the liver biopsy (Masson's trichrome, $\mathrm{x} 4$ ). 
Table 3: The histologic activity indices on the basis of the Ishak classification, of the liver biopsy pathological results, in accordance with the hepatitis types of the patients

\begin{tabular}{|c|c|c|}
\hline Histologic activity index & Hepatitis B & Hepatitis C \\
\hline Stage 0 & 3 & 0 \\
\hline Stage 1 & 5 & 1 \\
\hline Stage 2 & 6 & 6 \\
\hline Stage 3 & 3 & 0 \\
\hline Stage 4 & 1 & 1 \\
\hline Stage 5 & 1 & 0 \\
\hline Stage 6 & 0 & 5 \\
\hline
\end{tabular}

Two groups were formed according to the liver pathology results: 1) The group with liver fibrosis (Stage 1-5), and 2) The group without liver fibrosis (Stage 0). When these two groups were compared, no statistically significant difference was found between them, in terms of positive or negative chest CT findings for pulmonary fibrosis $(\mathrm{p}=$ 0.702). Another comparison was made between the Stage 0 and 1 patients and lung fibrosis patients, and the $\mathrm{p}$ value was found as 0.051 , which indicated a statistically insignificant finding.

\section{DISCUSSION}

Ignoring the hepatic biopsy results, it was found that in $43.8 \%$ of our cases there were findings of pulmonary fibrosis. The most frequently encountered fibrosis finding was the parenchymal band. Parenchymal bands are a very basic finding in fibrosis and indicate interstitial involvement. ${ }^{3}$ The probability of the presence of fibrotic bands in the lungs has been reported to be $78.6 \%$ in COPD, and $22.6 \%$ in healthy people. ${ }^{4}$ The prevalence in our case group was $34.3 \%$, higher than that of the above-mentioned healthy group. We attributed this fact to the abundance of our COPD patients, whose ratio was $25 \%$. On the other hand, statistical analyses indicated no statistically significant correlation between the liver and pulmonary fibrosis processes.

The term pulmonary fibrosis points to an abundance of fibrotic tissue in the lungs. Pulmonary fibrosis may be localized or segmental, and may even involve the whole lungs. Pulmonary fibrosis may arise due to various diseases; and fibrosis may ocur in the lungs due to many reasons. ${ }^{5}$ When pulmonary fibrosis is considered, the first and main pathology that comes to mind is idiopathic pulmonary fibrosis. But it must be kept in mind that fibrosis in the lungs may be the result of many diseases. For example, granulomatous diseases (sarcoidosis, tuberculosis), pulmonary infections, adult respiratory distress syndrome, coal/silica/asbest inhalation, cystic fibrosis, autoimmune diseases, radiation exposure and the use of various drugs, may lead to fibrosis. ${ }^{6}$ Our cases demonstrated parenchymal bands, subpleural linear densities, and interlobular septal thickenings, as findings of fibrosis, and we considered most of them to be sequelae.

Liver parenchymal biopsy is a standard procedure of our time and it is widely used with the purpose of determining histologic activity and the level of fibrosis. ${ }^{7}$ The histologic activity index score modified by Ishak et $\mathrm{al}^{8}$ is among the most widely utilized methods for the evaluation of biopsy results. Proper determination of the stage of liver fibrosis is of utmost importance both in the therapy planning and follow-up of chronic liver disease. .-10 $^{-10}$ Chronic hepatitis B and C may first lead to liver fibrosis, and then cirrhosis in the advancing stages of the disease. ${ }^{11}$ During this process, it is not surprising that the growth factors and cytokines which stimulate the formation and advancement of liver fibrosis also inflict the same effect on various other organs and tissues. The make-up of fibrosis in various organs takes place in 4 phases. Initially, damage is caused due to a known or unknown cause. The activation of effector cells follow this phase. During the third phase, the extracellular matrix is elaborated. The fourth and last phase creates fibrosis as a result of extracellular matrix accumulation. ${ }^{12}$ Common pathways exist in the process of fibrosis formation in various organs. The secretion of cytokines such as interleukin-8, tumor necrosis factor alpha, and interleukin-1, besides growth factors, and the activation of fibroblasts leading to the deposition of Type- 1 and Type- 3 collagen, may be emphasized as good examples to 
this phenomenon. ${ }^{13}$ Because tissue damage is the initial step for the formation of fibrosis, it may first come to mind that even though common pathways exist, one organ's fibrosis will not affect other organs' fibrosis. But we had speculated that systemic pathogens such as hepatitis viruses may inflict a similar tissue damage in the lungs, because they migrate through the systemic circulation. Besides, cytokines which form due to various other causes may inflict tissue damage and thus the formation of fibrosis, in the lungs. There is not an enough number of studies performed on humans on this subject, and new studies are needed in order to proceed on the issue. ${ }^{1}$

\section{The constraints of the study}

One of the limitations of our study was that it was structured retrospectively. Another drawback was the insufficiency of the number of patients. Had the study been structured prospectively, analysis of some growth factors and cytokines could have been possible. Because of the scarse number of our patients, we were not able to compare every individual liver fibrosis stage with the lung fibrosis findings. On the other hand, because COPD is an important causative factor of pulmonary fibrosis, it could have been better to exclude COPD patients from the study, in terms of obtaining more reliable results.

\section{CONCLUSION}

No statistically significant relation was found between the liver and pulmonary fibrosis processes seen in hepatitis B and C diseases. We suggest that larger randomized controlled studies be performed that will enable the comparison of pulmonary fibrosis findings with every stage of hepatic fibrosis.

\section{REFERENCES}

1. Makarev E, Izumchenko E, Aihara F, Wysocki PT, Zhu Q, Buzdin A. Common pathway signature in lung and liver fibrosis. Cell Cycle 2016; 15(13):1667-1673.

2. Cotran RS, Kumar V, Collins T. Pathology basic of disease. Philadelphia: WB Saunders Co, 1999.

3. Resorlu M, Arslan M, Karatag O, Adam G. Thorax Computed Tomography Findings in
Patients with Erectile Dysfunction. J Clin Imaging Sci 2017; 7:25.

4. Moreira MA, Barbosa MA, Queiroz MC, Teixeira KI, Torres PP, Santana Júnior PJ, et al. Pulmonary changes on HRCT scans in nonsmoking females with COPD due to wood smoke exposure. J Bras Pneumol 2013; 39:155-163.

5. Noble PW, Barkauskas CE, Jiang D. Pulmonary fibrosis: patterns and perpetrators. J Clin Invest 2012; 122(8):2756-2762.

6. Wallis A, Spinks K. The diagnosis and management of interstitial lung diseases BMJ 2015; 350:h2072.

7. Aygün C, Gözel N, Demirel U, Yalnız M, Özercan İH, Bahçecioğlu İH. Kronik viral hepatit B tanis1 olan hastalarda serum GGT düzeyi ile karaciğer fibrozu ilişkisi. Fırat Medical Journal 2010; 15:74-78.

8. Ishak K, Baptista A, Bianchi L, Callea F, De Groote J, Gudat $\mathrm{F}$ et al. Histological grading and staging of chronic hepatitis. J Hepatol 1995; 22:696-699.

9. Söker $\mathrm{G}$, Gülek B, Öztürk AB, Karabıyık Ö, Akın MA, Kaya Ö, Dilek O, Yilmaz C. The Value of Fibrosis Index in Discrimination of Chronic Hepatitis and Cirrhosis. Med Bull Haseki 2017; 55:212-215.

10. Davoudi Y, Layegh P, Sima H, Tatari S, Faghani R. Diagnostic Value of Conventional and Doppler Ultrasound Findings in Liver Fibrosis in Patients with Chronic Viral Hepatitis. J Med Ultrasound 2015; 23:123-128.

11. Soker G, Bahadir Ozturk A, Gulek B, Kuscu F, Bilge Doğan U, Yilmaz C. Doppler ultrasonography helps discriminate between cirrhotic and non-cirrhotic patients with viral B and $\mathrm{C}$ hepatitis. Diagn Interv Imaging 2016; 97:339-345.

12. Rockey DC, Bell PD, Hill JA. Fibrosis-a common pathway to organ injury and failure. $\mathrm{N}$ Engl J Med 2015; 372:1138-1149.

13. Walters EH, du Bois RM. Immunology and management of interstitial lung diseases London: Chapman \& Hall Medical, 1995. 